\title{
Conflict and Identity: The Ritual of Wall Construction in Early China
}

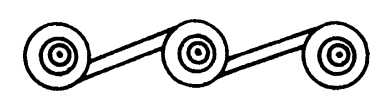

YANG Qian

\begin{abstract}
This article examines the rituals involved in wall construction in the Neolithic and Early Bronze Age of China. Since the building of a settlement wall required the involvement of most of the residents and the settlement gate was used as a public place, such rituals were probably conducted in public without any restrictions on the participants. During the Longshan period, when early states first formed in China, these ritual activities became increasingly elaborate and more humans were sacrificed. The people who were sacrificed were probably captives caught during warfare. Sacrificing enemies in public rituals can reinforce ethnic identity, which is conducive to the ideological formation of an early state. KeYwords: walled site, ritual, human sacrifice, social conflict, early state, China.
\end{abstract}

\section{INTRODUCTION}

Archaeologists ANALyze Ritual activities to investigate the emergence of power and hierarchical organizations in ancient societies. However, most studies on ritual strategies of the formative states in China focus on the elites who used rituals as part of their decision-making processes and tend to regard such rituals as strategies for acquiring social power (Flad 2008). Such strategies included conducting divination rituals to mediate uncertainty and hosting feasts to attract followers and acquire prestige in local and regional social settings (Clark and Blake 1994; D'Altroy 1994:177-178; Underhill 2002). Rituals, such as those held during elite funerals, often deployed prestigious items, including sometimes exotic materials associated with increased political power. The sourcing of materials from distant locations indicate the power of elites in ancient societies (Chang 1980; Helms 1993; Liu 2003).

Most of the current scholarship on the relationship between ritual and power examines private rituals, particularly those of elites (Smith 2002). Elites used ritualssuch as oracle bone divination, the consumption of large mammals during feasts, and the inclusion of prestige goods (e.g., jades, bronzewares, and cinnabar) in funerals - to establish and secure their positions. Since only elites had access to many of these goods, only they were able to participate in such rituals. While studying these private rituals neglects the perspective of non-elites, an analysis of public rituals enables scholars to understand how ritual activities affected non-elites. Public rituals were usually held in 
Table i. Chronological Sequence of Major Periods of Early China

\begin{tabular}{lll}
\hline TECHNOlogical Period & \multicolumn{1}{c}{ CUltural Period } & ABSOlute DAtes \\
\hline Neolithic & Yangshao & ca. 5000-3000 B.C. \\
& $\begin{array}{l}\text { Early-Middle Longshan } \\
\text { Late Longshan }\end{array}$ & ca. 3000-2500 B.C. \\
& ca. 2500-1900 B.C. \\
Bronze Age & Erlitou Culture & ca. 1900-1600 B.C. \\
& Shang Dynasty & ca. 1600-1046 B.C. \\
& Zhou Dynasty & ca. 1046-221 B.C. \\
\hline
\end{tabular}

open areas and often involved the participation of commoners. They brought together many members of society and strengthened the identity of the community.

This case study therefore examines the particular public rituals associated with wall construction at chengyi 城邑 (walled sites or settlements) in China from the Late Yangshao period (ca. 5000-3000 B.c.) to the Eastern Zhou period (770-221 B.c.) (Chang 2000:400) (Table 1). Walls or gates and unroofed courtyard spaces are ideal for communal rituals (Hastorf 2007). Using oracle bone inscriptions and historical documents along with archaeological evidence, I argue that wall construction rituals involved the participation of almost all settlement residents. The archaeological evidence includes ritual remains found in spaces that would have been open to all participants without limitation, particularly at walls and gates. Remains from these areas enable me to investigate the ritualization of wall construction and how rituals changed along with the transformation in sociopolitical organization across several time periods. I further discuss how wall construction rituals brought members of society together and strengthened community identity at these walled settlements.

\section{THEORETICAL FRAMEWORK}

Religion has long been considered to consist of both belief systems and ritual actions. Since symbolic meanings are embodied and formulated through ritual acts, the meanings of symbols can be interpreted by examining clues from historic and ethnographic documents (Geertz 1973). In addition, once an ideology is materialized in objects, material things become symbolic (DeMarrais et al. 1996; Robb, 1998). Thus, even in the absence of historic or ethnohistorical sources, archaeologists are able to infer at least some of the meanings of material symbols through careful examination of their material contexts (Fogelin 2007). Some scholars have challenged the idea that symbolic meanings remains stable, however (Bell 1997; Bloch 1986). They have argued that although specific rituals may remain the same for a long time, their symbolic meaning for society is constantly recontextualized (Fogelin 2007). Nevertheless, by combining historic and ethnographic documents with archaeological contexts, we may still gain insight on the possible symbolic meanings of certain rituals.

Another perspective on the study of ritual study involves focusing on ritual action and its effects. In the early twentieth century, Durkheim (1965 [1912]) argued that ritual exercises promote consensus and one of the psychological ramifications of such consensus is that people's minds are more easily controlled by their rulers. Since integrative action conveys a sense of shared group experience and social identities, participants in ritual ceremonies gain a sense of membership, which then produces 
communal solidarity (Hastorf 2007; Lewis 1980:6). Although Durkheim's notion has been critiqued, it suggested different aspects of conducting research on ritual. For example, what rituals do, rather than what rituals mean, can be explored through focusing on the actions of the individuals involved (Fogelin 2007). Studying ritual can also be an effective way to examine the social relations between ritual participants and how new social boundaries are constructed, stabilized, and reinforced in diverse social contexts (Aldenderfer 1993; Bowie 2000:154; Bradley 2003). In this respect, change in ritual over time should be emphasized because it is linked to sociopolitical transformations, especially ways in which the development of relationships of power are promoted (Flad 2001; Sugiyama 2014; Yuan and Flad 2005). This process, what Bell (1997) called ritualization, does not necessarily entail a relationship in which one social group has absolute control over another, but may be one that involves both consent and resistance, misunderstanding and appropriation.

Using archaeological materials to analyze change in ritual over time and contextualize the meaning of the ritual in different periods is better than relying on historical documentation alone to understand the meaning and function of a ritual. In this article, I analyze the ritual activities involved in wall construction at different periods of early China to explore the particular contexts in which these ritual activities took place and how they played out in terms of social relations. I find that wall construction rituals became increasingly formulaic with the addition of animal and human sacrifice in the Late Longshan period (ca. 2500-1900 B.c.). Sacrificing humans as part of wall construction rituals during this period effectively integrated the community and supported the formation of early states in China.

\section{HISTORICAL DOCUMENTATION OF WALL CONSTRUCTION RITUAL PRACTICES AND PARTICIPANTS}

Who participated in wall construction rituals and ritual processes are revealed in the earliest written records of China, the oracle bone inscriptions of the Late Shang period (1250-1046 B.c.), and continued to be recorded in written documents into the Imperial period.

\section{Ritual Participants}

Documents from pre-Imperial (before 221 B.C.) to Imperial (ca. 221 B.C.-A.D. 1912) China reveal information about who participated in building walls and who likely participated in wall construction rituals in historical times. Local commoners, regardless of their usual occupation or gender, were often involved in wall construction. For example, during the early Ming dynasty (ca. fourteenth century A.D.), more than one million people, including soldiers, servants, craftspeople, and prisoners, helped construct the Nanjing city wall. Although the wealthy did not physically participate in the construction, they were required to donate money to supplement the government funds allocated to build the wall (Yang G. 2002). Furthermore, during wartime, everyone living in an enclosed city was responsible for defending the wall. For instance, when enemies attacked Xiangyang city in A.D.378 (during the Eastern Jin Dynasty), General Zhuxu led the entire city population to fight and protect the wall. His mother is recorded as having "organized around a hundred maidservants . . . to help rebuild the 67 meter long northwestern wall” (Jinshu 2000:1420). ${ }^{1}$ 
The areas around the gates to walls were probably significant due to their unique function as a public space for settlement residents. People usually did not live close to city walls for security reasons, which left open spaces around these areas. Sometimes temples were located near a gate. For instance, two temples were located just inside the Qian Gate, the south gate of Beijing in the late Qing dynasty (early twentieth century A.D.). The eastern temple was known as the Guanyin Temple and the western temple was the Guandi Temple. Both temples were open to all city residents and frequented by worshippers (Sirén 1924). Due to the large numbers of people flowing through city gates, government administrators also attached official bulletins on the wall closest to each gate to convey news to the public. The "Haoling 号令 [Command]" chapter of Mozi 墨子 [Mozi's Thoughts], probably written in the fourth century B.C. (Li 2006), describes how officials posted bulletins on the streets, main roads, and city gates, allowing passersby to read official statements (Mozi 1993:899). ${ }^{2}$

The gate leading into the capital usually served as a space for festivities, as well as taking in captives or decapitating traitorous soldiers (Xu 2015). Public sacrifice of human beings at a city gate was therefore probably associated with warfare. Examples of this occur in the Zuozhuan 左传 [Zuo's Commentary], a detailed chronicle of the Spring and Autumn periods (770-481 B.C.) compiled during the Warring States era (480-221 B.C.):

[In 696 B.C.] The Souman tribe invaded Qi in the second year of the reign of that state's Duke Xiang, and Prince Chengfu captured another one of Qiao Ru's young brothers named Rong Ru. The Prince had his captive's head chopped off and buried beneath the northern gate of the city of Zhoushou. A third young brother, Jian Ru, was taken prisoner by forces of the state of Wei, and this effectively put an end to the threat from the tribe of Souman. 齐襄公之二年, 毁瞒伐齐, 齐王子成父获其弟荣如, 埋其首于周首 之北门。卫人获其弟简如。毁瞒由是遂亡。(Zuozhuan:384)

[In 632 B.C.] Duke Wen of Jin besieged the Cao capital, but many of his soldiers were killed trying to conquer the city gate. In order to show their power, the men of Cao took the dead bodies of the Jin soldiers and exposed them on the city wall. Fearing that it might cause some confusion among his army, the Jin ruler adopted his subordinates' suggestion to move some of his [dead] men to the graveyard where the Cao ancestors were buried. Hearing this, the men of Cao were immediately filled with panic and horror. After taking the dead bodies of the Jin soldiers from their coffins, they moved them out of the city. Taking advantage of this moment of panic, the Jin army made a fierce attack. On the tenth day of the third month they entered the Cao capital and captured its ruler. 晋侯围曹, 门焉, 多死, 曹人尸诸城之上, 晋侯患之。听與人之谋, 称 “舍于墓”。师迁焉。曹 仁凶惧, 为其所得者, 棺而出之。因其凶也而攻之。 (Zuozhuan:288)

[In 616 B.C.] On the third day of the tenth month, in winter, the Lu forces clashed with the enemy at Xian, in Lu territory. Qiao Ru, chief of the Souman tribe, was captured. Fufu Zhongsheng chopped the chieftain's head off and had it buried beneath the Ziju Gate in the outer wall of the capital of $\mathrm{Lu}$. This gate was thereafter named the Qiao Ru Gate. 冬十 月甲午, 败狄于咸, 获长狄侨如。富父终甥春其喉, 以戈杀之, 埋其首于子驹之门, 以命宣伯。”并以亡将之名“侨如” 命名其子, 用以纪功。(Zuozhuan:384)

\section{Ritual Processes and Practices}

Descriptions from oracle bone inscriptions and historical documents from pre-Imperial China show that divination rites and sacrifices were widely performed during wall 
construction as early as the late pre-Imperial period corresponding to the Shang and Zhou dynasties. The process of wall construction began with a king divining the location for a new settlement. Several inscriptions in the Jiaguwen Heji 甲骨文合集 [Book of the Collection of Oracle Bone Inscriptions], cited hereafter as Heji, depict royal concern with establishing a new site:

Crack-making on the day of Gengwu: a person named Bing divined to ask the god whether the king should not build the city here; Di will approve. 庚午卜, 丙贞, 王勿作 邑在兹, 帝若。(Heji 1978:inscription 86)

Crack-making on the day of Renzi: Que divined, we will build a city 壬子卜, 靔贞, 我作邑。(Heji 1978:inscription 13491)

Crack-making the day of Jiayin: Que divined, we will build a city. Approved. 甲寅卜， 靔贞, 我作邑, 若。(Heji 1978:inscription 13495)

A later document entitled “Luogao 洛诰 [The Announcement of Luo]," a chapter in the Shangshu 尚书 [The She King] written around the fifth century B.C. (see Shangshu 2014, annotated by Legge), records Duke Zhou's report to King Cheng about the divinatory process of choosing the location for Luoyi 洛邑, a capital city shared with the Western Zhou. Several locations were considered until the final one was chosen:

I arrived in Luo on the day of Yimao as planned. I divined [asked the oracle] whether the Li River valley was good. I divined whether the area between the eastern Jian River valley and the western Chan River valley was good. Only Luo was good. I divined [about] the eastern Chan River valley. Again, only Luo was good. 予惟乙卯, 期至于 洛师。我卜河朔黎水。我乃卜涧水东, 潳水西。惟洛食。我卜瀍水东, 亦惟洛食。

(Shangshu 2014:156)

After the location was chosen, rituals were held at the selected site before construction began. No clear descriptions of such rituals are found in oracle bone inscriptions, but another chapter in the Shangshu 尚书 entitled “Zhaogao 召诰 [The Announcement of the Duke of Zhou]" records Duke Zhou's ritual performances when establishing Luoyi 洛邑:

The next day on Yimao, Duke Zhou arrived in Luo in the morning and thoroughly inspected the plans for the new site. On the day of Dingsi, the third day after, he offered two bovines as sacrifices in the suburbs and Wuwu sacrificed a bovine, a goat, and a pig on the following day at the altar to the spirit of the land at the new site. 若翼日乙卯, 周公朝 至于洛，则达观于新邑营。越三日丁巳，用牲于郊，牛二。越翼日戌午，乃社于新 邑, 牛一、羊一、豕一。(Shangshu 2014:143-144)

Divinations and other specific rituals were required to ensure the success of each step in construction, including building a wall or gate (Cai 1999:167; Wen and Yuan 1983:385), as seen in the following oracle bone inscriptions.

Crack-making on the day of Jiashen, we would build the western wall. We would need more people. Crack-making on the day of Jiashen, we would build the western wall. The seventh month. 甲申卜, 我墉于西, 多氏人。甲申卜, 我墉于西, 七月。 (Heji 1978: inscription 136)

On a Bingyin day, we divined to ask whether it would rain on the day of Dingmao, because on this day they would tamp earth to build a wall. On the day of Yihai, we tamped 
earth to build a wall, and we divined to ask whether it would be showery today. 丙寅卜, 丁卯其垁, 景雨。乙亥卜, 今日其垁, 不皂雨。(Heji 1978:inscription 33871)

Installing gate, it would rain. 门, 其雨。(Heji 1978:inscription 1324)

Before building a western wall, the Shang people held a divinatory ritual to find out if they would need more laborers to complete the wall. They also wanted to know whether or not the weather would be conducive to building a wall or installing the gate. Tamping the earth between frames requires wet soil (Chen 2012), while installing a gate requires dry weather.

Oracle bone inscriptions mention other gate construction rituals conducted during the Shang dynasty (Qu 1984:187; Song 2010:63-67):

Performing ritual to worship the god of the gate by dismemberment [of an] animal. 帝乇 燎门 (Heji 1978:inscription 22246)

Crack-making on the day of Bingshen: Because it is not auspicious, we would perform the kan ritual to the god of the gate. Is the day of Xinchou good? The twelfth month. 丙申卜, 勿口, 陷于门, 辛丑用。十二月 (Heji 1978:inscription 19800)

The construction and maintenance of walls required the labor of a large number of people, as well as high input of resources and technical ability (Trigger 1990). Historical documents and oracle bone inscriptions also demonstrate that wall construction involved numerous divinatory and other ritual performances. Once constructed, gateways served as public spaces for the residents, and various rituals often took place at the gates, at least in the late pre-Imperial period. In light of this information, I now turn to archaeological evidence to explore whether such public rituals were conducted in earlier periods in China and, if so, how they might have contributed to community integration and the development of Chinese civilization.

ARCHAEOLOGICAL EVIDENCE FOR THE RITUALIZATION OF

WALL CONSTRUCTIONS IN EARLY CHINA

In oracle bone inscriptions, the character “yi 邑” (walled settlement) was originally composed of two parts: a rectangle on top and a person in a kneeling position at the bottom. An early version of this character can be seen in the lower right corner of the oracle bone in Figure 1. The rectangle and the person allude to two major elements of walled settlements in ancient China: the walls that surrounds them and the residents who live inside them. Previous studies have used the presence of walls as one of the main characteristics for identifying Chinese city sites (Chang 1977; Chang 2000:400; von Falkenhausen 2008). Archaeologists have now discovered nearly two hundred walled sites from the Yangshao period (ca. 5000-3000 B.c.), Longshan period (ca. 3000-1900 B.C.), Erlitou Culture and Shang Dynasty (ca. 1600-1046 B.C.) in China (Zhang and Yin 1997; Zhao and Wei 2002).

Walled sites during these periods were mainly rectangular, but sometimes round, and surrounded by moats. Some had sloped inner or outer revetments. Each city wall had between one to three gates and occasionally more walls were built outside the gate or the principal wall. Walls were built from rammed earth or stone, with stone walls more common in northern China. In the Shang Dynasty, wall construction began with the digging of a rectangular wall trench with a narrow bottom but a wide top, then 


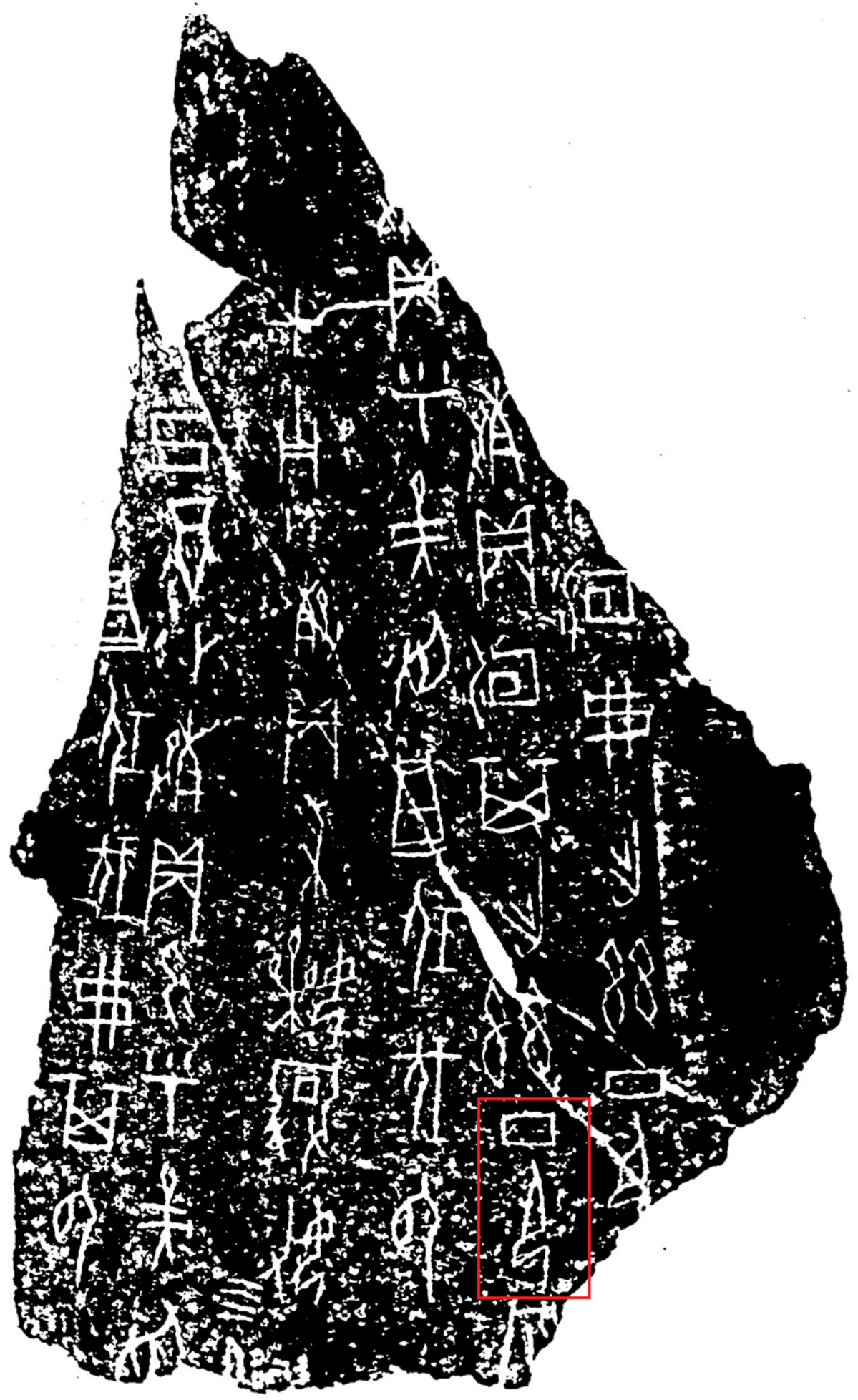

Fig. 1. Character for yi on front of oracle bone No. 7854 (Heji 1978:1192, photo used by permission from Zhonghua Book Company). 
Table 2. Wall Construction Ritual Locations and Remains

\begin{tabular}{|c|c|c|c|c|c|}
\hline WALLED SITE & LOCATION OF RITUAL REMAINS & $\begin{array}{c}\text { RITUAL } \\
\text { FEATURE }\end{array}$ & OFFERINGS & NOTES & SOURCI \\
\hline \multicolumn{6}{|c|}{ Yangshao Period } \\
\hline Chengtoushan & In southern wall & & Several piled fired bricks with charcoal ash & & Hunan 2007 \\
\hline Chengtoushan & In eastern wall & Pit M706 & 1 male adult skeleton & Head outside pit & Hunan 2007 \\
\hline Xishan & Under northern wall base & & 1 ding tripod & & Guojia 1999 \\
\hline Xishan & In northern wall base & & 1 guan jar & & Guojia 1999 \\
\hline Xishan & In northern wall & & $\begin{array}{l}1 \text { painted bo bowl containing bones of } \\
\text { infant, } 1 \text { ding tripod, } 1 \text { guan, }>10 \text { other } \\
\text { pottery vessels }\end{array}$ & & Guojia 1999 \\
\hline Xishan & Below western gate & Pit $\mathrm{H} 1818$ & $\begin{array}{l}>20 \text { pottery vessels: ding tripods, guan jars, } \\
\text { yan steamers, } h u \text { kettles, wan bowls, weng } \\
\text { urns }\end{array}$ & & Guojia 1999 \\
\hline \multicolumn{6}{|c|}{ Early-Middle Longshan Period } \\
\hline Bianxianwang & $\begin{array}{l}\text { In wall base near south gate of inner } \\
\text { city }\end{array}$ & & 1 ding tripod, 1 guan pot & $\begin{array}{l}\text { Intact ceramic vessels } \\
\text { placed with mouths } \\
\text { facing up }\end{array}$ & Shandong 2015 \\
\hline Bianxianwang & $\begin{array}{l}\text { In wall base near south gate of inner } \\
\text { city }\end{array}$ & & 1 ding tripod, 1 bei cup & & Shandong 2015 \\
\hline Bianxianwang & In north wall base of inner city & Pit D6 & 1 pig skeleton & Age: $13-18$ months & Shandong 2015 \\
\hline Bianxianwang & $\begin{array}{l}\text { In west wall base near west gate of } \\
\text { outer city }\end{array}$ & Pit D7 & 1 yan tripod & & Shandong 2015 \\
\hline Bianxianwang & $\begin{array}{l}\text { In west wall base near west gate of } \\
\text { outer city }\end{array}$ & Pit D8 & 1 dog skeleton & & Shandong 2015 \\
\hline Bianxianwang & $\begin{array}{l}\text { In west wall base near west gate of } \\
\text { outer city }\end{array}$ & Pit D9 & 1 human skeleton & Without feet & Shandong 2015 \\
\hline Bianxianwang & $\begin{array}{l}\text { In west wall base near west gate of } \\
\text { outer city }\end{array}$ & Pit D10 & 1 human skeleton & $\begin{array}{l}\text { Hands crossed in front of } \\
\text { chest }\end{array}$ & Shandong 2015 \\
\hline Bianxianwang & $\begin{array}{l}\text { In west wall base near west gate of } \\
\text { outer city }\end{array}$ & Pit D11 & 1 dog skeleton, 1 pig jaw & & Shandong 2015 \\
\hline Bianxianwang & $\begin{array}{l}\text { In west wall base near west gate of } \\
\text { outer city }\end{array}$ & Pit D12 & 1 wan bowl, 1 dou plate, 1 animal jaw & & Shandong 2015 \\
\hline Bianxianwang & In west wall base near west gate of & Pit D13 & 1 pottery gui tripod, 2 dog jaws & & Shandong 2015 \\
\hline
\end{tabular}


TABLE 2. (Continued)

\begin{tabular}{|c|c|c|c|c|c|}
\hline WALLED SITE & LOCATION OF RITUAL REMAINS & $\begin{array}{c}\text { RITUAL } \\
\text { FEATURE }\end{array}$ & OFFERINGS & NOTES & SOURCE \\
\hline Bianxianwang & $\begin{array}{l}\text { In west wall base near west gate of } \\
\text { outer city }\end{array}$ & Pit D14 & 1 human skeleton & In kneeling position & Shandong 2015 \\
\hline Bianxianwang & $\begin{array}{l}\text { In west wall base near west gate of } \\
\text { outer city }\end{array}$ & Pit D30 & 1 dog skeleton & Without skull & Shandong 2015 \\
\hline Bianxianwang & $\begin{array}{l}\text { In west wall base near west gate of } \\
\text { outer city }\end{array}$ & Pit D31 & 1 dog skull & & Shandong 2015 \\
\hline Bianxianwang & In northeast wall base of outer city & Pit D17 & 1 pig skeleton & & Shandong 2015 \\
\hline Bianxianwang & In northeast wall base of outer city & Pit D19 & 1 pig skeleton & $\begin{array}{l}\text { 18-25 months old, } \\
\text { missing lower limbs }\end{array}$ & Shandong 2015 \\
\hline Bianxianwang & In northeast wall base of outer city & Pit D21 & 2 human skeletons, 6 human skulls & & Shandong 2015 \\
\hline Bianxianwang & In northeast wall base of outer city & Pit D24 & Human skeletons & Only lower limbs & Shandong 2015 \\
\hline Bianxianwang & In northeast wall base of outer city & Pit D26 & 1 dog skeleton & & Shandong 2015 \\
\hline Bianxianwang & In northeast wall base of outer city & Pit D27 & 1 pig skeleton & & Shandong 2015 \\
\hline Bianxianwang & In northeast wall base of outer city & Pit D28 & 1 dog skeleton & $\begin{array}{l}\text { Fractured skull, limbs } \\
\text { separated from body }\end{array}$ & Shandong 2015 \\
\hline Jingyanggang & $\begin{array}{l}\text { Western stairs of small platform near } \\
\text { wall }\end{array}$ & & 1 goat & & $\begin{array}{l}\text { Shandong \& Liaocheng 1997; } \\
\text { Zhang } 1996\end{array}$ \\
\hline Jingyanggang & $\begin{array}{l}\text { Western stairs of small platform near } \\
\text { wall }\end{array}$ & Round pit & $\begin{array}{l}1 \text { cow, }>20 \text { pottery vessels including a weng } \\
\text { urn }\end{array}$ & & $\begin{array}{l}\text { Shandong \& Liaocheng 1997; } \\
\text { Zhang } 1996\end{array}$ \\
\hline Jingyanggang & Beneath southwestern wall & & Human skulls & & $\begin{array}{l}\text { Shandong \& Liaocheng 1997; } \\
\text { Zhang } 1996\end{array}$ \\
\hline Jiaochangpu & In northern wall base & Pit JSK8 & $\begin{array}{l}\text { Large amount of pottery including guan jar, } \\
h u \text { kettles }\end{array}$ & $\begin{array}{l}\text { Fracture caused by a } \\
\text { strong blow found on } \\
\text { the lower limbs of an } \\
\text { adult }\end{array}$ & $\begin{array}{l}\text { Zhongguo Shehui, Shandong } \\
\text { \& Liaocheng } 2005\end{array}$ \\
\hline Jiaochangpu & In northern wall base & Pit JSK10 & $\begin{array}{l}14 \text { pottery vessels, male adult pelvic bone } \\
\text { and lower limb, one female child's skull }\end{array}$ & & \\
\hline
\end{tabular}


TABLE 2. (Continued)

\begin{tabular}{|c|c|c|c|c|c|}
\hline WALLED SITE & LOCATION OF RITUAL REMAINS & $\begin{array}{c}\text { RITUAL } \\
\text { FEATURE }\end{array}$ & OFFERINGS & NOTES & SOURCE \\
\hline \multicolumn{6}{|c|}{ Late Longshan Period } \\
\hline Wangchenggang & In northeast corner of western wall & Pit H64 & $\begin{array}{l}1 \text { child skeleton laid on layer of pottery } \\
\text { sherds }\end{array}$ & $\begin{array}{l}\text { Skull separated from } \\
\text { neck; left tibia } \\
\text { separated from femur }\end{array}$ & Beijing \& Henan 2007 \\
\hline Wangchenggang & In northern moat & & 1 human skull & & \\
\hline Guchengzhai & Under base of southern wall & & 2 child skeletons & In ceramic coffins & Henan \& Xinmi 2002 \\
\hline Taosi & In wall base & Ditch IHG8 & $\begin{array}{l}31 \text { human individuals; } 4 \text { human skulls; } \\
\text { several human post-cranial remains, } 35 \\
\text { year old female human skeleton with ox } \\
\text { horn in pelvis; skeleton of animal, dog } \\
\text { skeletons, scattered animal bones }\end{array}$ & $\begin{array}{l}\text { Some skulls have } \\
\text { evidence of blunt force } \\
\text { trauma }\end{array}$ & $\begin{array}{l}\text { He 2013; Zhongguo Shehui, } \\
\text { Shanxi \& Linfen } 2005\end{array}$ \\
\hline Pingliangtai & In southwestern corner & Pit $\mathrm{H} 53$ & 2 cattle skeletons, pottery vessels & & Henan \& Zhoukou 1983 \\
\hline \multicolumn{6}{|c|}{ Late Longshan Period - Erlitou Culture } \\
\hline Shimao & Outside northeastern wall & $\mathrm{K} 1$ & 24 human skulls & Mostly young females & Shannxi et al. 2013 \\
\hline Shimao & Entrance of eastern gate of outer city & K2 & 24 human skulls & Mostly young females & Shannxi et al. 2013 \\
\hline Shimao & In stone wall & & $\begin{array}{l}\text { Jade chan spades; jade huang semicircular } \\
\text { pendants }\end{array}$ & & Shannxi et al. 2013 \\
\hline Shimao & In collapsed southern wall & & $\begin{array}{l}\text { Carved stone sculptures in shape of human } \\
\text { heads }\end{array}$ & & Shannxi et al. 2013 \\
\hline \multicolumn{6}{|l|}{ Shang Dynasty } \\
\hline Yanshi & Near western wall of large city & & 1 human skeleton & & $\begin{array}{l}\text { Du 2003; Zhongguo Shehui } \\
\text { 2002; Zhongguo Shehui } \\
\text { Luoyang 1984; Xie 2015; } \\
\text { Liu \& Chen } 2012\end{array}$ \\
\hline Yanshi & Near northern wall of large city & $\mathrm{T} 2 \mathrm{M} 2$ & 1 human skeleton & & \\
\hline Yanshi & In western wall & M11 & 1 child skeleton, 1 guan jar & & \\
\hline Yanshi & In western wall & & $>20$ fired bricks, 1 pig skull & & \\
\hline Zhengzhou & Under western wall & Pit GK18 & 4 dog skeletons & $\begin{array}{c}1 \text { dog at each of } 4 \\
\text { corners of pit }\end{array}$ & Henan \& Zhengzhou 1977 \\
\hline
\end{tabular}


TABLE 2. (Continued)

\begin{tabular}{|c|c|c|c|c|c|}
\hline WALLED SITE & LOCATION OF RITUAL REMAINS & $\begin{array}{c}\text { RITUAL } \\
\text { FEATURE }\end{array}$ & OFFERINGS & NOTES & SOURCE \\
\hline Zhengzhou & Bottom of northern wall & & Human skulls, ribs, pelvic bone, limbs & & Henan \& Zhengzhou 1977 \\
\hline Zhengzhou & Wall base & 8 pits & 92 dog skeletons & & Henan \& Zhengzhou 1977 \\
\hline Huaibei & In western wall & & Dog skeletons, pig skulls & & $\begin{array}{l}\text { Zhongguo Shehui Anyang } \\
\text { 2003; Tang et al. } 2000\end{array}$ \\
\hline Mengzhuang & $\begin{array}{l}\text { Beneath rammed earth of eastern } \\
\text { wall }\end{array}$ & Pit $\mathrm{H} 18$ & 1 pig skeleton & & Henan 2003 \\
\hline Wangjinglou & Beneath northern wall & & 1 human skeleton & & Zhengzhou 2016 \\
\hline Yuanqu & Outside west gate & & $\begin{array}{l}1 \text { human skeleton, several cobblestones, } 6 \\
\text { pottery sherds }\end{array}$ & $\begin{array}{l}\text { Obvious fracture remains } \\
\text { on bones }\end{array}$ & $\begin{array}{l}\text { Dong 1997; Zhongguo Lishi } \\
\text { et al. } 1996\end{array}$ \\
\hline \multicolumn{6}{|c|}{ Zhou Dynasty } \\
\hline Gaocheng & $\begin{array}{l}\text { Between rammed earth layers of } \\
\text { northern wall }\end{array}$ & & 1 human skull, 1 pig skeleton & & Henan et al. 2008 \\
\hline
\end{tabular}


earth was tamped from the bottom to the top of the trench layer by layer. Next the rammed area was expanded beyond the trench while tamping the trench top. Lastly, the main wall bodies were built by tamping soil into the space between the frames. After that, inclined revetments were added to both sides of the main wall and a moat was dug around the wall (Beijing 1979:58-60; Yang and Ma 2010:359-366).

Unequivocal archaeological evidence of divinatory rituals being conducted prior to wall construction (like those mentioned on oracle bones) does not exist for early China. However, the remains of rituals that likely occurred during the construction of walls and gates have been found in the base and body of various walls and in the vicinity of gates, especially outer gates (Table 2, Fig. 2). Ritual offerings were put between different layers of rammed earth in walls, sometimes in special small shallow pits intentionally dug. The soil in these pits is pure and compacted and identical to the rammed earth of the walls. Consequently, the boundaries between some of the pits are difficult to distinguish. Unlike the ritual remains in the walls, some ritual remains found in the vicinity of gates lack stratigraphic information. As indicated by the written records discussed earlier, some of these remains probably were deposited during or after gate construction.

Ritual remains associated with construction, especially during the construction of walls and gates, have been unearthed at eighteen sites (Fig. 3). Due to current excavation practices, these findings represent a small part of the actual ritual remains associated with wall constructions. In China, the primary purpose of excavating large settlement sites is to examine the scope, construction technique, and the dates of the walls. Archaeologists only examine gate construction as a secondary goal. Consequently, trench excavation is often applied in the excavation of walls. Due to the limited area excavated, the ritual remains discovered in association with wall constructions are almost certainly fewer than the actual number of ritual remains.

Despite these limited discoveries, it is still useful to compare the archaeological remains to determine the nature of the rituals conducted at different major time periods in early China (see Table 1). Such discoveries shed light on the ritualization of wall construction and the process of this ritual change along with transformations in sociopolitical organization.

\section{Yangshao (ca. 5000-3000 B.c.)}

Social inequality emerged in the late Yangshao period. Rich grave goods excavated from high-ranking burials provide evidence for social stratification (Zhongguo and Henan 2010:293-298). Settlements have been divided by size into three tiers, including large and medium-sized sites and small villages (Ma 2005:11-28; Xu 2002). During this period, walled sites became increasingly popular and some walls (such as at the Xishan site described below) seem to have had a defensive function.

The earliest ritual remains associated with wall construction are found at the Chengtoushan 城头山 site of Daxi Culture (ca. 4500-3300 B.c.)in the middle of China in what is now Hunan Province (Fig. 3, No. 2). Several piled-up, fired bricks along with charcoal ash were found in the southern wall of the site. A shallow round pit (M706) in the rammed earth of the eastern wall contained the remains of a male adult; his head was found outside the pit (Hunan 2007:92-93,142).

The Xishan 西山 site of Yangshao Culture, located in northwest China's Henan Province (Fig. 3, No. 1), was arranged in an irregular round shape, but had some 


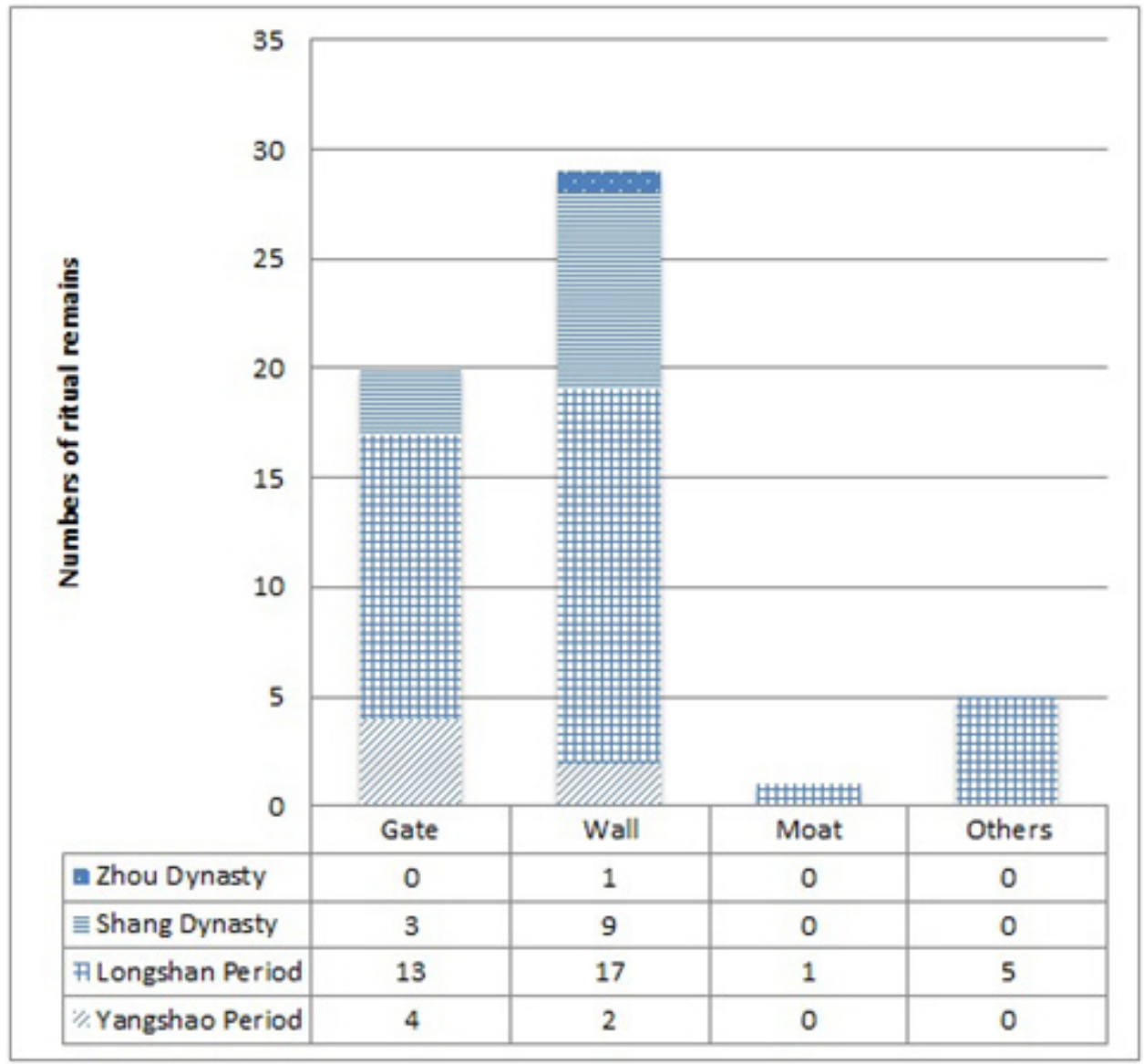

Fig. 2. Frequency of ritual remains in different archaeological features.

defensive features including a 4-5 $\mathrm{m}$ high wall and a moat that was $4-11 \mathrm{~m}$ wide and 3-4.5 $\mathrm{m}$ deep. Towers were built next to the west gate and the northern gate was shielded by another section of wall $7 \mathrm{~m}$ long by $1.5 \mathrm{~m}$ thick. According to the Shouchenglu Zhushi 守城录 [A Book about City Defense], originally written by Chen Gui 陈规 during the Song Dynasty (early twelfth century A.D.), this secondary "wall functioned as a partition to prevent people outside from knowing whether the gate was open or closed 所以遮隔冲突。门之启闭, 外不得知” (Shouchenglu 1990:64). Archaeologists discovered the following remains in the west part of the northern wall: a ceramic ding tripod under the base of the wall; a guan jar in the base of the wall; and a painted bo bowl containing the bones of an infant, a ceramic ding tripod, another pottery guan, and more than ten pottery vessels in the wall itself. Additionally, more than 20 pottery vessels, including ding tripods, guan jars, yan steamers, $h u$ kettles, wan bowls, and weng urns, were found in pit H1818 below the western gate (Guojia 1999) (Fig. 4).

Based on the number of ritual offerings found at each site, pottery seems to have been the primary offering throughout the Yangshao period (Fig. 5). Ceramic vessels are found standing with their mouths facing up in these ritual contexts. This suggests 


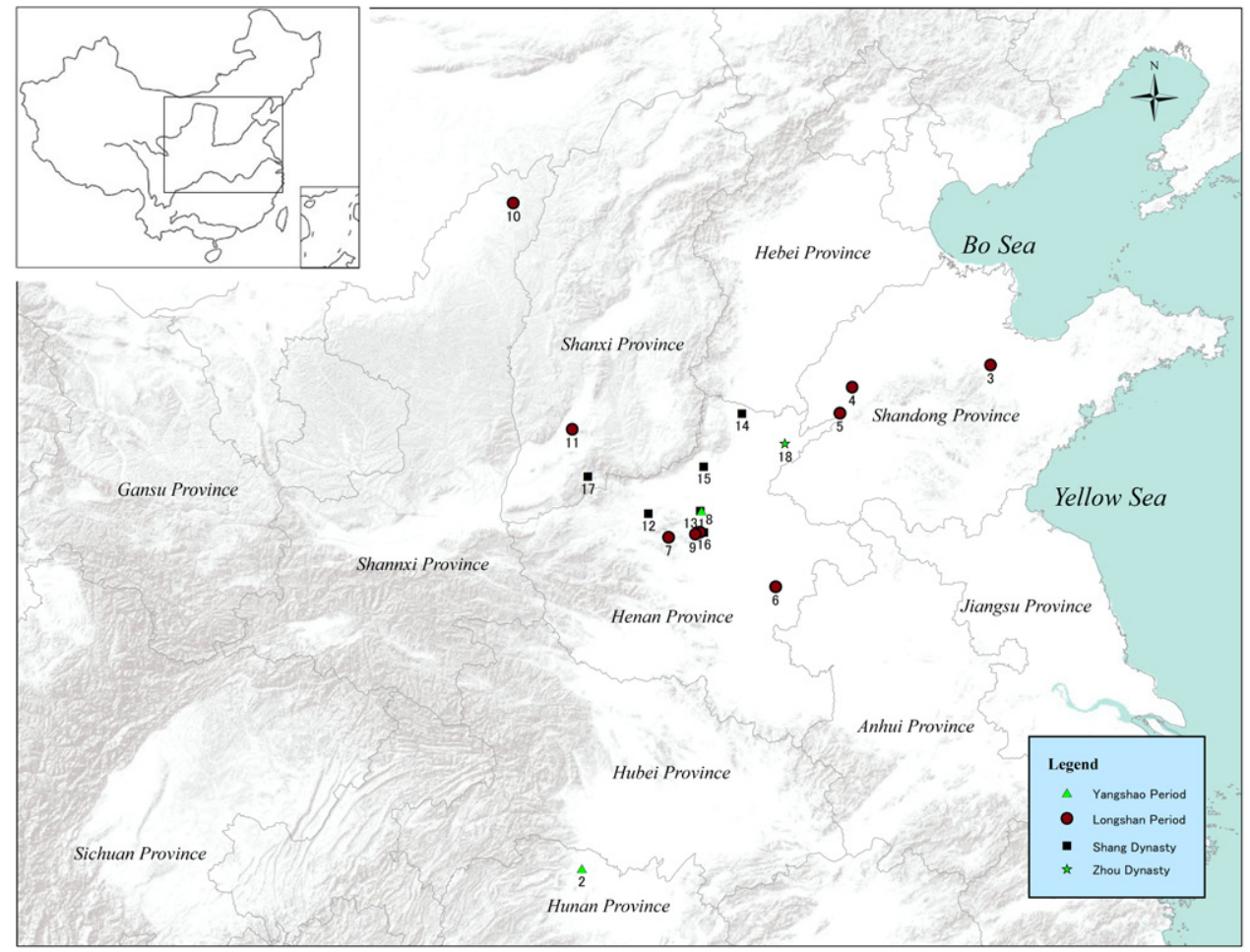

Fig. 3. Walled sites with ritual remains found in wall construction contexts: 1. Xishan; 2. Chengtoushan; 3. Bianxianwang; 4. Jiaochangpu; 5. Jingyanggang; 6. Pingliangtai; 7. Wangchenggang; 8. Guchengzhai; 9. Xinzhai; 10. Shimao; 11. Taosi; 12. Yanshi Shang Walled Site; 13. Zhengzhou Shang Walled Site; 14. Huanbei Shang Walled Site; 15. Mengzhuang; 16. Wangjinglou; 17. Yuanqu Shang Walled Site; 18. Gaocheng.

that they may have been deliberately arranged upright. Since no residue analysis has yet been conducted on these pottery vessels, their contents remain unknown.

Early to Middle Longshan (ca. 3000-2500 B.C.)

More remains have been found for the early and middle Longshan periods than for the Yangshao period. Offerings range from pottery vessels to animal and human sacrifices. Although ceramic vessels remained the dominant offering, they rarely appear on their own but instead are usually found with other offerings. At the Jingyanggang 景阳冈 site in east China (Shandong Province) (Fig. 3, No. 5), ritual remains were found in association with two platforms of different sizes. Ritual pits located on the western stairs of a small platform contained bones of a complete goat. Skeletal remains of a cow and piled sherds from more than 20 vessels were found at the bottom of a round pit three meters in diameter and located in the northeastern corner of the smaller platform. Pottery vessels were likely broken intentionally prior to burial in these pits. Human skulls were also found beneath the rammed earth of the southwestern wall at this site (Shandong and Liaocheng 1997; Zhang 1996). 
a.

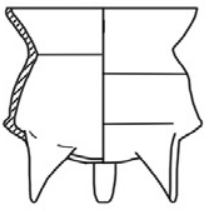

Ding (H1818:20) 1/10

b.

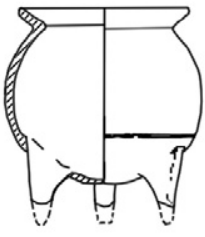

Ding (H1818:3) 1/10

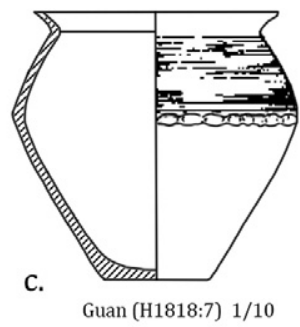

d.

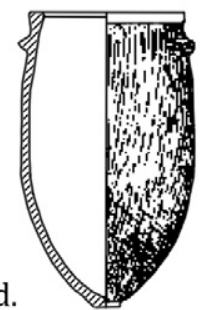

Gang (H1818:23-1) 1/20

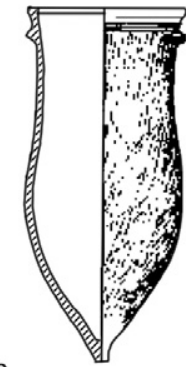

Gang (H1818:24-1) 1/20

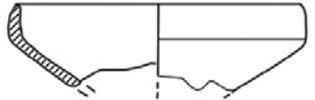

f.

Bo (H1818:24-1) 1/10

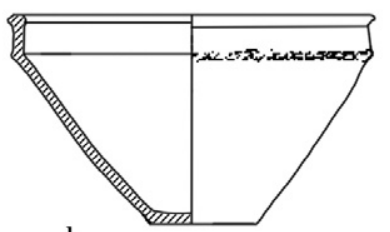

h. Pen (H1818:23-2) $1 / 10$

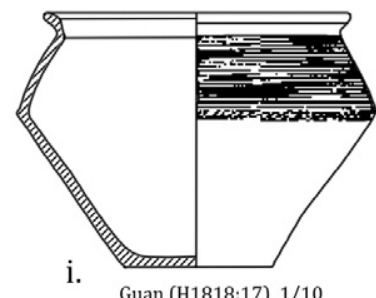

Fig. 4. Pottery remains from pit H1818, Xishan (after Guojia 1999:9, fig. 6).

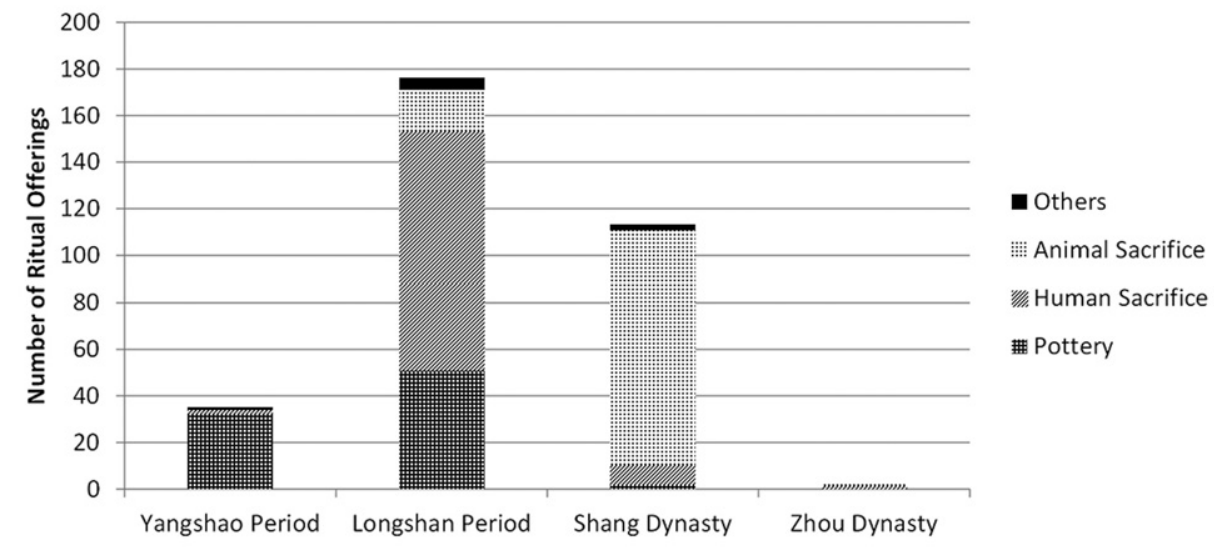

Fig. 5. Ritual offerings by type at different chronological periods. 


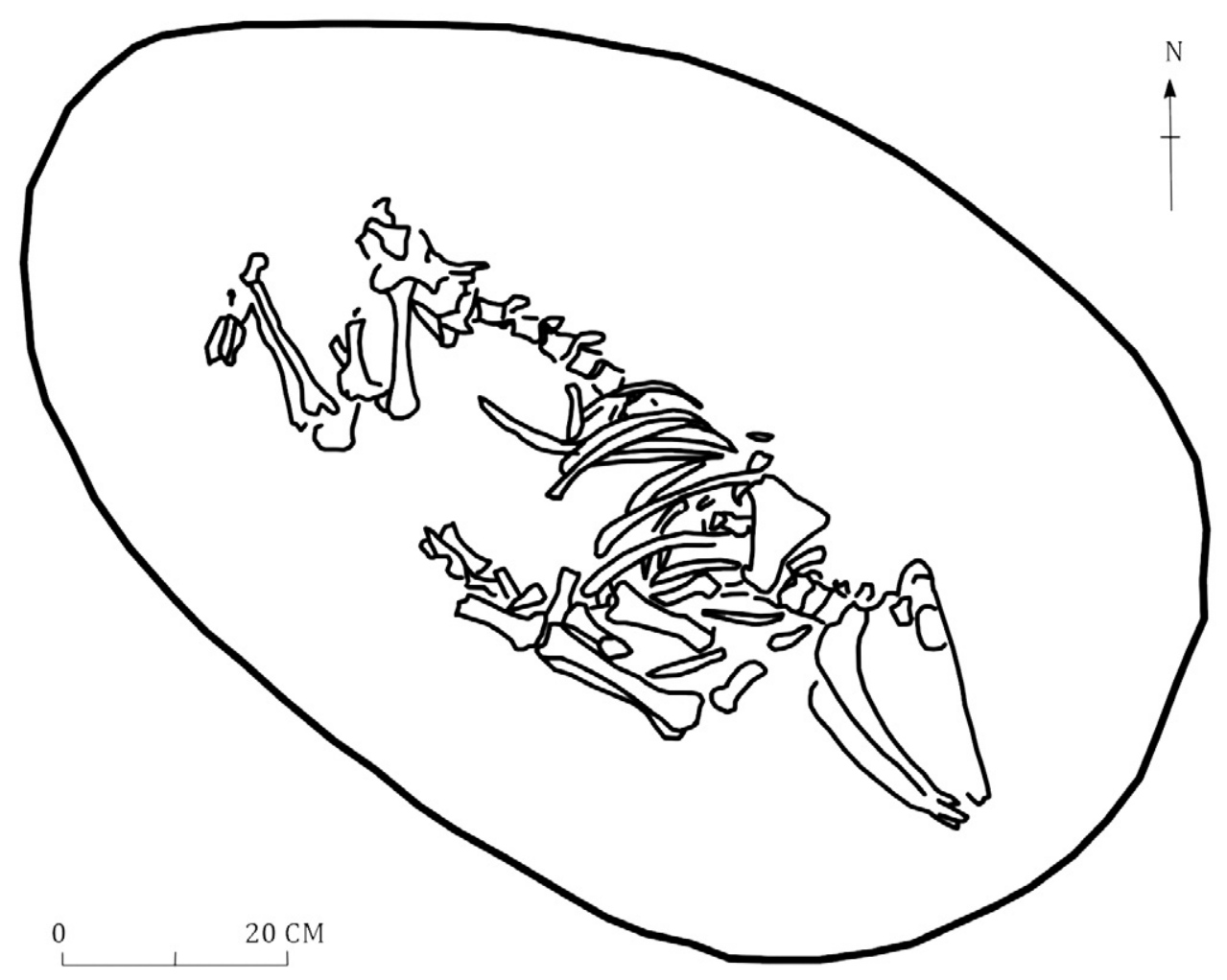

Fig. 6. Pig skeleton in pit D17 at Bianxianwang (after Shandong 2015:29, photo 26).

Many walls, especially those that had a defensive function, were repeatedly rebuilt. The wall of the Jiaochangpu 教场铺 site in Shandong Province was built twice, for example (Fig. 3, No. 4). The first wall was built directly on the ground and surrounded by a moat. Residents later refurbished the wall to make it higher and wider. Five ritual pits were found at this site containing pottery vessels and human and animal remains; these pits seem to have been dug before the wall was constructed for the second time. A fracture caused by a strong blow appears on the lower limbs of the skeleton of an adult found at the Jiaochangpu site (Zhongguo Shehui, Shandong, and Liaocheng 2005).

These ritual finds suggest that, in addition to offering pottery vessels that had already been used in the Yangshao period, animals were introduced into wall construction rituals in the early and middle Longshan period. Pigs, dogs, cattle, and goats were the four main taxa for animal sacrifices. Most of the animals were sacrificed whole, as represented by the intact goat skeleton found in the pits on the western stairs of the small platform at the Jingyanggang site. Only a small number of jaws or skulls have been found, however.

The remains of 31 rituals (partially listed in Table 2) have been found around the gates or in the walls of the Bianxianwang 边线王 site in east China (Fig. 3, No. 3). Human victims, pigs, dogs, and pottery vessels were used as offerings. A human skeleton found in a kneeling position in the external base of the wall indicates that the sacrificial victim was bound. Two sacrificed pigs, one 13-18 months old and the other 18-25 months old according to preliminary zooarchaeological analysis, were also 
found (Shandong 2015:1-54). Figure 6 shows how the skeleton of the older pig was arranged in pit D17. Very little is known about the role of animal sacrifice in these early rituals, however, and zooarchaeological research on many other sites is still needed.

As seen at the Jingyanggang, Bianxianwang, and Jiaochangpu sites, humans were sacrificed and offered during wall construction rituals of the early and middle Longshan periods. However, compared to pottery vessels and animal sacrifices, humans were not the main category of offerings during these early periods (Fig. 5).

\section{Late Longshan (ca. 2500-1900 B.C.) to Erlitou Culture (ca. 1900-1600 B.C.)}

Several cultural traits mark a new stage of social development during the Longshan period, especially the Late Longshan. Paleoclimatic records show an abrupt cooling period around 2200 B.C., which is associated with less precipitation and the silting of rivers (Feng et al. 2004; Shi, Kong and Wong 1992; Shi et al. 1993; Weiss 2000). At the same time, the population density reached its peak in this period. In Henan Province alone, the estimated population doubled from 1,073,000 in the Late Yangshao to 2,090,000 in the Late Longshan (Wang 2011:341-347).

Corresponding to the pressure of rising populations and limited resources, competition amongst social groups increased. The presence of prestige goods used as offerings in wall construction rituals in the Late Longshan period reflect this change. For example, in ditch H53 in the southwestern corner of the Pingliangtai 平粮台 site (Fig. 3, No. 6), archaeologists unearthed two bovine skeletons and some mostly grey pottery vessels, including ding tripods, guan jars, and yan steamers; a small number of more elaborate pottery objects such as polished black vessels were also uncovered (Henan and Zhoukou 1983). Social competition lead to political integration and military domination. Archaeological records show that the number of arrows found in the Wei River valley increased rapidly (Liu 1996). In Henan and Shandong provinces, arrows and other weapons were prevalent, and some skeletons in burials are found without skulls or lower limbs, which indicates that warfare or violence occurred at this time (Liu and Chen 2005; Underhill 1989).

Such social changes took place in all regions around the middle and lower Yellow River valley and ultimately led to the emergence of the early state in China. Some of the Longshan period walled sites with ritual remains were located in the peripheral areas of the central plain along with other communities; this is where the Xia dynasty, the earliest state mentioned in Chinese classical texts, emerged. The Jiaochangpu and Jingyanggang sites were located in the western part of Shandong Province. This was a buffer zone between the Dongyi ethnic group in the east and the Huaxia in the central plain. The Shimao site is located in the area between the agriculturalists and nomadic groups to the north. These regions faced higher possibilities of large-scale armed conflicts in comparison to other places.

In such contexts, walls increasingly had a defensive function. This function is particularly obvious at Shimao, which not only had an enclosed stone inner wall and an outer wall, but also watchtowers, turrets, barracks, and auxiliary structures similar to bastions (Shannxi et al. 2013). The Longshan period of increased warfare also coincides with a transition in ritual offerings from more pottery to greater human sacrifice. According to narratives in the classical Zuozhuan text, such rituals acted as psychological warfare to weaken the enemy and strengthen the victor's confidence and show off their victory to the public. The Zuozhuan $(1996: 288,384)$ describes at least two 


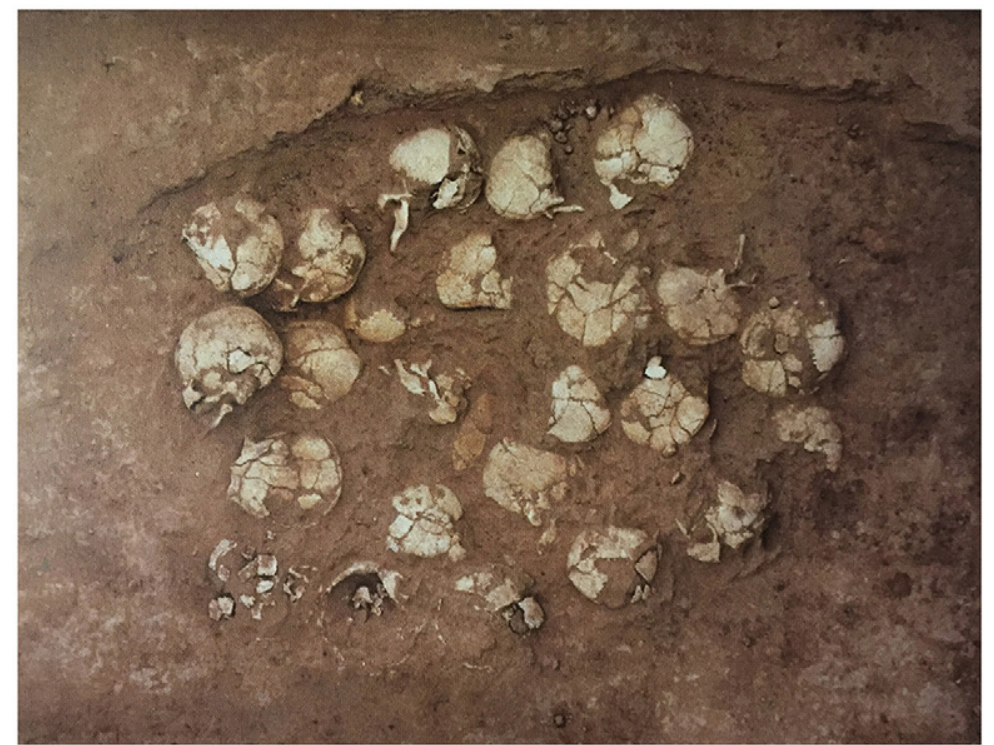

K1

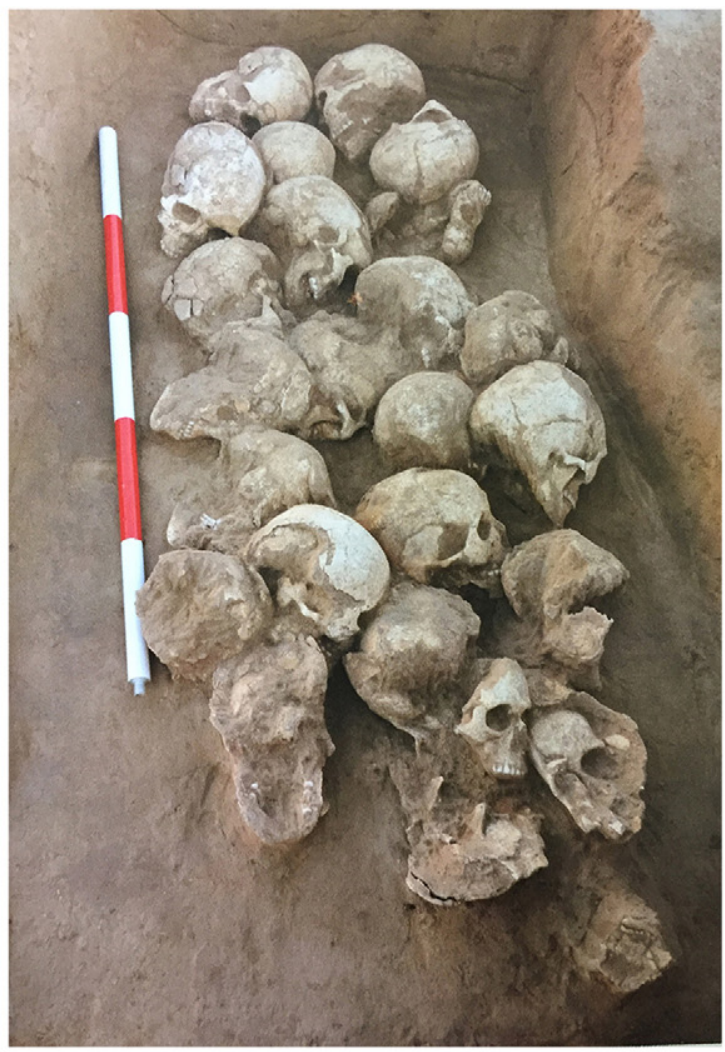

K2

Fig. 7. Sacrificial pits K1 and K2 at Shimao (after Shannxi et al. 2013:23, photos 14, 15). 
kinds of warfare rituals involving human victims and conducted at walled sites. In one ritual, dead bodies were exposed on the wall and in the other, skulls were buried under the gate. The latter practice is supported by archaeological discoveries at Wangchenggang, Shimao, and Taosi sites.

Whatever their purpose, human sacrifice at walled sites became more common during the Late Longshan period. Most human victims were adults, but some child remains have been found at Wangchenggang 王城岗 and Guchengzhai 古城寨. For instance, at the Guchengzhai site in the central plain (Fig. 3, No. 8), the skeletons of two children were found beneath the base of the southern wall. Each child was buried in its own pottery coffin. The first child (W1) was placed in a guan jar and gang vat, while the second child (W2) was in a coffin made of two pottery gang vats (Henan and Xinmi 2002).

Unlike what is seen in the remains of animal offerings, evidence of violent trauma can be identified on some of the human skeletal remains of the Late Longshan period. For example, many skulls separated from the rest of the skeletons of human sacrifices have been unearthed. This indicates that these victims were probably beheaded. At the Wangchenggang site in the central plain (Fig. 3, No. 7), archaeologists found a human skull in the northern moat. They also uncovered a sacrificial pit (H64) full of rammed earth in the northeastern corner of the western wall, in which the skeleton of a child was laid on a layer of pottery sherds. The skull of this child had been separated from the neck and the left tibia was separated from the femur (Beijing and Henan 2007:68).

In ditch IHG8 located on the base of the wall at the Taosi 陶寺 site in the Fen River valley of Shanxi Province (Fig. 3, No. 11), objects were buried in three different layers. Skulls of at least 31 individuals, mostly adults but including one child and one elderly male, were found in the first layer. Some skulls are found with cervical vertebrae. All the skulls show evidence of blunt force trauma. In the middle layer, skeletons of an animal, four human skulls, and several human post-cranial remains were discovered. A large number of dog skeletons, scattered animal bones, human skulls, and a complete skeleton of a 35-year old female with an ox horn inserted in her pelvis were found in the third layer (He 2013; Zhongguo Shehui, Shanxi, and Linfen 2005).

Decapitation was probably conducted on a large scale in the Late Longshan, as dozens of skulls piled together have sometimes been found. Located in northern Shaanxi Province, Shimao 石峁 is the largest known walled site dating from the Late Longshan through to Erlitou Culture periods in China (Fig. 3, No. 10). Among all contemporaneous walled sites, the greatest number of ritual remains have been found at Shimao. Archaeologists found two pits with dense deposits of human skulls buried in the outer walled area, including K1 outside of the northeastern wall and K2 at the entrance of the eastern gate. Twenty-four human skulls (mostly from young females) were buried in each pit (Fig. 7). Some jade chan tablets and jade semicircular huang pendants were inserted into the stone wall. Carved stone sculptures in the shape of human heads were also unearthed from a collapsed southern wall (Shannxi et al. 2013).

\section{Shang Dynasty (ca. 1600-1046 B.C.)}

While Shimao is the only Erlitou Culture site to contain ritual remains in association with wall construction, ritual remains have been found in six walled sites dating to the Shang Dynasty, including: Yanshi Shang Walled Site 偃师商城 (Du 2003; Liu and 
Chen 2012:278-284; Xie 2015; Zhongguo Shehui 2002; Zhongguo Shehui Luoyang 1984); Zhengzhou Shang Walled Site 郑州商城 (Henan and Zhengzhou 1977); Huanbei Shang Walled Site 洹北商城 (Tang et al. 2000; Zhongguo Shehui Anyang 2003); Mengzhuang 孟庄 (Henan 2003:306); Wangjinglou 望京楼 (Zhengzhou 2016); and Yuanqu Shang Walled Site 垣曲商城 (Dong 1997; Zhongguo Lishi et al. 1996:164) (Fig. 3, Nos. 12-17). All these walled sites were located in the central plain of China; the first three sites have been identified as capital sites of the Early and Middle Shang periods (An 1961; Tang et al. 2000; Zou 1999).

Human sacrificial victims have been found at the Yanshi, Zhengzhou, Wangjinglou, and Yuanqu sites, but in far fewer numbers than at Longshan period sites. Furthermore, most human skeletons found in the vicinity of the walls are complete and show no evidence of trauma. For instance, a human skeleton, several cobblestones, and six pottery sherds were found just four meters from the west gate of the Yuanqu Shang walled site.

Pottery vessels were rarely used in the Shang period sacrificial contexts. Instead, animals (especially dogs and pigs) were sacrificed during these rituals. At the Zhengzhou Shang walled site, some partial human bones were found in pit GK18. Some partial human bones were found at the bottom of the rammed northern wall, but $92 \mathrm{dog}$ skeletons were found distributed among eight pits at almost the same level as the wall base, including one dog placed at each of the four corners of a rectangular pit in the western wall. Dog skeletons and pig skulls were also unearthed in large quantities in the middle excavation trench of the west wall of the Huanbei Shang walled site. At the Mengzhuang site, a pig skeleton was found in an oval pit (H18) beneath the rammed earth of the east wall (Henan 2003:306).

Dogs were popular in Shang rituals because that they were regarded as a masculine animal that could exorcise evil (Dong 1997; Gao 2000:291-303; Huang 2004:3-4; Wang 1995). The Shiji 史记 [Records of the Grand Historian] mentions:

In June of the second year of Qinde Emperor (ca. 676 B.c.), Qin people killed dogs to ward off the disease named hot miasma. 二年, 初伏, 以狗御盅。

To which one of the annotators to the Shiji, Zhang Shoujie 张守节, added the following note:

Dog is recorded as a masculine animal. Killing dogs at four outer-city gates could avert the hot miasma in June which is the beginning of the coming summer. 六月三伏之节起秦德 公为之, 故云初伏。伏者, 隐伏避盛暑也。......磔, 禳也。狗, 阳畜也。以狗 张磔于郭四门, 禳却热毒气也。(Shiji 1959:184)

The Shang state was involved in integrating different polities that were constantly in conflict with each other. According to oracle bone inscriptions, Shang, the strongest polity in the region, fought against one hundred other polities (Wang and Yang 1999:498-499). Warfare became even more frequent in the Late Shang period and its war against Renfang 人方 is thought to have accelerated the collapse of the Shang state (Luo 2010:298-333).

In the context of warfare and instability, rituals that established men as kings became central (Fiskesjö 2001), while other rituals, including those associated with wall construction, became less important (Campbell 2007). This is evident in the decline of ritual remains found in association with settlement walls or gates. For example, no city or palace walls have been found at the Yinxu 殷墟 site, which was the capital of the 
Late Shang dynasty, whereas large sacrificial pits containing humans, animals, and objects have been found within the palatial zone and royal cemetery (Li 1977:3-48; Liu and Chen 2012:355-360). A total of 576 human skeletons were found to the south of the Yiqi 乙七 (II-7) palace foundation. These people were probably sacrificed during ancestor worship rituals and their remains indicate the significance of ancestor worship at this time (Liu 2000; Yang B. 2002:97-118). Some of these human victims were defeated rebels or barbarians brought back to Anyang. They were used as sacrifices in community-preserving rituals meant to mitigate uncertainty and danger (Campbell 2014).

\section{Zhou Dynasty (ca. 1046-221 B.c.)}

Among the walled sites of the Zhou Dynasty, ritual remains associated with wall constructions have only been found at the site of Gaocheng 高城, the capital of the Wei state. A human skull was found between the two rammed earth layers (No. 3B and No. 4) of the northern wall. It was probably while the rammed earth layer No.3B was being repaired. A young pig skeleton that had been smashed to pieces was found between the rammed earth layers No. 6 and No. 7 (Henan et al. 2008).

Remains of walled enclosures became particularly scarce in the Western Zhou period (ca. 1046-771 B.c.). None of the various Western Zhou capitals were walled and ritual remains at the perimeter of these sites are absent (von Falkenhausen 2008). Note, however, that this absence may be due to the lack of consistent archaeological excavations of these Zhou period settlements.

\section{DISCUSSION AND CONCLUSION}

Objects such as ceramic vessels, humans, animals, jades, and carved stone sculptures, unearthed during archaeological excavations of early Chinese settlements, seem to have been used as offerings in sacrificial rituals associated with wall construction. Pottery was the most common ritual object involved in wall construction rituals during the Yangshao period, whereas human sacrifices became more prevalent during the Longshan period. Sacrificing dogs (also mentioned in historical documents) only became popular during the Shang and Zhou dynasties.

The changes in types of offerings at different periods suggests that the symbolic meanings of the rituals probably varied as well. Changes in ritual offerings occurred in tandem with the development of social complexity. Rituals associated with wall construction appeared in the Yangshao period and became ubiquitous in the Longshan period; such practices were especially prevalent in the middle and lower Yellow River. The wall construction ritual was most prevalent during the Late Longshan period, which coincides with early state formation in China (Liu and Chen 2005; Shelach and Jaffe 2014). The ritual remained popular in the Shang Dynasty, but then declined and only one case has so far been found for the Zhou Dynasty.

Although I mainly categorize the wall construction ritual as a public ritual by analogy with the later historical record, some evidence has emerged that these public rituals occurred in earlier periods in China. The process of ritualization in wall construction, including ritual sacrifice, began to be held in public settings as early as the Neolithic period (Table 1). For example, at the eastern gate of the Shimao site where wall construction ritual remains were found, archaeologists found other indicators that 
rituals conducted there were open to all residents, including murals with colored geometric patterns on the wall. These remains were related to ritualized performance and display, and were perhaps relevant to nature worship (Li 2017).

In the Late Longshan period, emerging states were relatively unstable political entities. Conflicts within and between states increased as social inequality increased. Given such ongoing conflict, political elites would have sought methods to address instability and promote a common identity and sense of allegiance amongst citizens. Identity refers to the ways in which individuals and collectives are distinguished in their social relations with other individuals and collectivities (Jenkins 1996:4). It is difficult to identify ethnic groups based on only distinctions of language, culture, territory, or religion. Instead, an ethnic identity involves socially constructing a feeling of "us" versus "the other" (Jones 1997:60-61). Constructing a common ethnic identity then plays a significant role in the formation of a state identity.

By reducing fear when a society faces a crisis far beyond its ability to solve or is in the midst of a hegemonic struggle, rituals serve as a valuable means for instilling a common identity formation (Lessa and Vogt 1979:38). Rituals not only express people's social dependence but also help define the boundaries of the most important social group, the elites to whom other individuals give allegiance (Kertzer 1991). People's allegiances are often rooted in their social identification with the larger group, so regular reenactment of rituals can strengthen people's attachment to a regime. In the eve of the formation of early states, when social conflict is most intense, holding public rituals is particularly conducive to generated a united ideology and reducing anxiety (Homans 1941). Within marked spaces and with prescribed sequences of actions, rituals construct a kind of society where events are remembered and referred to later in daily and domestic contexts, extending the place of ritual throughout a society (Hastorf 2007).

Wall construction rituals were public. The historical sources from the late preImperial to Imperial periods reveal that there were no restrictions (i.e., by gender, occupation, or social status) on those who participated in constructing walls and therefore on those who viewed wall construction rituals. The archaeological evidence further reveals that wall construction rituals became formalized by the Late Longshan period, and more humans began to be sacrificed during these ritual activities. Sacrificing humans in public ritual, especially those who are considered enemies, reinforces community integration and group identify. Public sacrifices of enemies were intentionally performed at settlement walls and gates to help integrate the audience into a social group (Bell 1997:159; Flad and Chen 2013:209). Group members gradually realized that they had formed a community of interests and traditions, the ethnic identity of "us" became established, and the ideological basis for early states came into existence. It is no coincidence that public human sacrifice at walls peaked during the same period as early states formed in China.

\section{ACKNOWLEDGEMENTS}

I gratefully acknowledge the financial support received from the National Social Science Fund of China (No. 17CKG008). Many thanks to Hui Fang at Shandong University and Qinzhu Wang and Rong Fan at Yale University for their help and thoughtful comments. Rodion Kosovsky and Mitchell Ma helped me a lot with the English. I also sincerely thank the Editors of Asian Perspectives. They give me some very fruitful and useful comments. 


\section{NOTES}

1. “序母韩自登城履行, 谓西北角当先受弊，遂领百余婢并城中女子于其角斜筑城二十余丈。 [Ms. Han, Zhu's mother, climbed the city wall herself and found that the northwestern wall was in danger of being attacked by the enemy. She then organized around a hundred maidservants and female residents in the city to help rebuild the 67 meter long northwestern wall]" (Jinshu 2000:1420).

2. “置署街街倠阶若门, 令往来者皆视而放。[Officials posted bulletins on the streets, main roads, and city gates, allowing passersby to read official statements]” (Mozi 1993:899).

\section{REFERENCES CITED}

ALDENDERFER, MARK

1993 Ritual, hierarchy, and change in foraging societies. Journal of Anthropological Archaeology 12:1-40.

AN JINHUAI 安金槐.

1961 Shilun Zhengzhou Shangdai Chengzhi: Aodu 试论郑州商代城址一隞都 [Discussion of the Zhengzhou Shang walled site: The capital of Ao]. Wenwu 文物 4,5:73-80.

Beijing Daxue Kaogu Wenbo Xueyuan 北京大学考古文博学院 and Henan Sheng Wenwu Kaogu YANJIUSUO 河南省文物考古研究所.

2007 Dengfeng Wangchenggang Kaogu Faxian Yu Yanjiu 登封王城岗考古发现与研究 [Excavation and Research of the Wangchenggang Site in Dengfeng, 2002-2005]. Zhengzhou: Elephant Press.

Beijing Daxue Lishixi Kaogu Jiaoyanshi Shangzhouzu 北京大学历史系考古教研室商周组.

1979 Shangzhou Kaogu 商周考古 [The Archaeology of Shang and Zhou Dynasties]. Beijing: Relics Press.

Bell, Catherine M.

1997 Ritual, Perspectives and Dimensions. Oxford: Oxford University Press.

Bloch, Maurice

1986 From Blessing to Violence: History and Ideology in the Circumcision Ritual of the Merina of Madagascar. Cambridge Studies in Social and Cultural Anthropology, vol. 61. Cambridge: Cambridge University Press.

BOWIE, FIONA

2000 The Anthropology of Religion. Oxford: Blackwell.

BRADLEY, RICHARD

2003 A life less ordinary: The ritualization of the domestic sphere in later prehistoric Europe. Cambridge Archaeological Journal 13(1):5-24.

CAi ZHEMAO 蔡哲茂

1999 Jiagu zhuiheji 甲骨缀合集 [Catalogue of Rejoined Oracle Bones]. Taipei: Lexue Press.

Campbell, Roderick B.

2007 Blood, Flesh and Bones: Kinship and Violence on the Social Economy of the Late Shang. Ph.D. diss. Harvard University.

2014 Transformations of violence: On humanity and inhumanity in Early China, in Violence and Civilization: Studies on Social Violence in History and Prehistory: 94-118, ed. Roderick B. Campbell. Oxford: Oxbow Books.

Chang, KwANG-ChiH

1980 Shang Civilization. New Haven: Yale University Press.

2000 Qingtong Huizhu 青铜挥塵 [Collected Papers Regarding the Chinese Bronze Age]. Shanghai: Shanghai Literature and Art Press.

Chang, Sen-Dou

1977 The morphology of walled capitals, in The City in Late Imperial China: 75-100, ed. William Skinner. Stanford, CA: Stanford University Press.

CHEN NIANFU 陈年福.

2012 Jiaguwen Xingtong Xingsizi Kaoshi Erze 甲骨文形同形似字考释二则 [Similar words in oracle bone inscriptions]. Ligeng Xuekan: Yuyanjuan 励耘学刊: 语言卷 2:207-214. 
Clark, John E., and Michael Blake

1994 The power of prestige: Competitive generosity and the emergence of rank societies in lowland Mesoamerica, in Factional Competition and Political Development in the New World: 17-30, ed. Elizabeth M. Brumfiel and John W. Fox. Cambridge: Cambridge University Press.

D’Altroy, Terence N.

1994 Factions and political development in the central Andes, in Factional Competition and Political Development in the New World: 171-188, ed. Elizabeth M. Brumfiel and John W. Fox. Cambridge: Cambridge University Press.

DeMarrais, Elizabeth, Luis Jaime Castillo, and Timothy Earle

1996 Ideology, materialization, and power strategies. Current Anthropology 37(1):15-31.

DONG QI 董琦.

1997 Chengmen Zheren: Yuanqu Shangcheng Yizhi Yanjiu Zhier 城门磔人一一垣曲商城遗址 研究之二 [Killing people outside the gate: The research on Yuanqu Shang walled site (Part 2)]. Wenwu Shijie 文物世界 (1):68-71.

DU JINPENG 杜金鹏

2003 Yanshi Shangcheng Chutan 偃师商城初探 [Research on Yanshi Shang Walled Site]. Beijing: China Social Sciences Press.

Durkheim, Emile

1965 The Elementary Forms of the Religious Life. New York: The Free Press.

[1912]

Feng Zhaodong, An Chengbang, and Tang Lingyu

2004 Stratigraphic evidence of a megahumid climate between 10,000 and 4000 years B.P. in the western part of the Chinese loess plateau. Global and Planetary Change 43:145-155.

Fiskesjö, Magnus

2001 Rising from blood-stained fields: Royal hunting and state formation in Shang China. Bulletin of the Museum of Far Eastern Antiquities 73:49-191.

FLAD, ROWAN

2001 Ritual or structure? Analysis of burial elaboration at Dadianzi, Inner Mongolia. Journal of East Asian Archaeology 3(3-4):23-52.

2008 Divination and power: A multi-regional view of the development of Oracle Bone Divination in Early China. Current Anthropology 49(3):403-437.

Flad, Rowan, and Pochan Chen 陈柏桢

2013 Ancient Central China: Centers and Peripheries along the Yangzi River. New York: Cambridge University Press.

Fogelin, LARS

2007 The archaeology of religious ritual. Annual Review of Anthropology 36:55-71.

GAO GuANGREN 高广仁

2000 Haidaiqu Xianqin Kaogu Lunji 海岱区先秦考古论集 [Comprehensive Studies on Archaeology of the Haidai Region in Pre-Qin Times]. Beijing: Chinese Science Press.

Geertz, Clifford

1973 Religion as a cultural system, in The Interpretation of Cultures: 87-125. New York: Basic Books.

Guojia Wenwuju Kaogu Lingdui Peixunban 国家文物局考古领队培训班

1999 Zhengzhou Xishan Yangshao Shidai Chengzhi De Fajue 郑州西山仰韶时代城址的发掘 [Excavation of a Yangshao site of a city in the outskirts of Zhengzhou]. Wenwu 文物 7:4-15.

Hastorf, Christine A.

2007 Archaeological Andean rituals: Performance, liturgy, and meaning, in The Archaeology of Ritual: 77-108, ed. Evangelos Kyriakidis. Los Angeles: Cotsen Institute of Archaeology.

$\mathrm{HE} \mathrm{Nu}$

2013 The Longshan period site of Taosi in Southern Shanxi Province, in A Companion to Chinese Archaeology: 255-277, ed. Anne Underhill. Chichester: Wiley-Blackwell.

HEJI 合集

1978 Jiaguwen Heji 甲骨文合集 [Book of the Collection of Oracle Bone Inscriptions], ed. Zhongguo Shehui Kexueyuan Lishi Yanjiusuo 中国社会科学院历史研究所. Beijing: Zhonghua Book Company. 
Helms, Mary W.

1993 Craft and the Kingly Ideal: Art, Trade and Power. Austin: University of Texas Press.

Henan Sheng Bowuguan 河南省博物馆 And ZhengZhou Shi Bowuguan 郑州市博物馆

1977 Zhengzhou Shangdai Cheng Yizhi Fajue Baogao 郑州商代城遗址发掘报告 [Excavation Report of Zhengzhou Shang Walled Site]. Wenwu Ziliao Congkan 文物资料丛刊 (1):1-31.

Henan Sheng Wenwu KaOgu YanjIUSUO 河南省文物考古研究所

2003 Huixian Mengzhuang 辉县孟庄 [Mengzhuang Site in Hui County]. Zhengzhou: Zhongzhou Ancient Books Press.

Henan Sheng Wenwu Kaogu Yanjiusuo 河南省文物考古研究所, Shoudu Shifan Daxue Lishi XueYuan 首都师范大学历史学院, AND PUYANG SHI WeNwU BAOHU GUANLISUO 泆阳市文物保护管理所

2008 Henan Puchengxian Gaocheng Yizhi Fajue Jianbao 河南溔阳县高城遗址发掘简报 [Excavation report of Gaocheng Site Puyang County, Henan Province]. Kaogu 考古 3:18-30.

Henan Sheng Wenwu Kaogu Yanjiusuo 河南省文物考古研究所 AND XINMI Shi Yanhuang Lishi WENHUA YANTAOHUI 新密市炎黄历史文化研究会

2002 Henan Xinmi Shi Guchengzhai Longshan Wenhua Chengzhi Fajue Jianbao 河南新密市古城 寨龙山文化城址发掘简报 [Excavation on the Guchengzhai city site of Longshan Culture in Xinmi City, Henan Province]. Huaxia Kaogu 华夏考古 2:53-82.

Henan Sheng Wenwu Yanjiusuo 河南省文物研究所 And Zhoukou Diqu Wenhuaju Wenwuke 周口 地区文化局文物科

1983 Henan Huaiyang Pingliangtai Longshan Wenhua Chengzhi Shijue Jianbao 河南淮阳平粮台 龙山文化城址试掘简报 [Trial diggings at the site of the ancient city of Longshan Culture at Pingliangtai in Huaiyang, Henan Province]. Wenwu 文物 3:21-36.

Homans, George C.

1941 Anxiety and ritual: The theories of Malinowski and Radcliffe-Brown. American Anthropologist 43:164-172.

HUANG ZHANYUE 黄展岳

2004 Gudai Rensheng Renxun Tonglun 古代人牲人殉通论 [On Ancient Human Immolation]. Beijing: Relics Press.

Hunan SHENG Wenwu KaOgu Yanjiusuo 湖南省文物考古研究所

2007 Lixian Chengtoushan: Xinshiqi Shidai Yizhi Fajue Baogao 澧县城头山一新石器时代遗址发掘 报告 [Chengtoushan in Lixian: Excavation Report of a Neolithic Site]. Beijing: Cultural Relics Publishing House.

JENKINS, RichARD

1996 Social Identity. London: Routledge.

JINSHU 晋书

2000 Jinshu 晋书 [History of the Jin Dynasty], by Fangxuanling 房玄龄. Beijing: Zhonghua Press.

JONES, SIÂN

1997 The Archaeology of Ethnicity: Constructing Identities in the Past and Present. London: Routledge.

KertZer, DAVID I.

1991 The role of ritual in state-formation, in Religious Regimes and State-Formation: Perspective from European Ethnology: 85-103, ed. Eric R. Wolf. Albany: State University of New York Press.

Lessa, William A., and Evon Z. Vogt, eds.

1979 Reader in Comparative Religion: An Anthropological Approach. New York: Joanna Cotler Books.

Lewis, GiLbert

1980 Day of Shining Red. Cambridge: Cambridge University Press.

Li GUANGHUI

2006 Mozi Chengshu Niandai Ji Zhuzhe Kaozheng Zongshu 《墨子》成书年代及著者考证综述 [Summary on the research of the time and the author of Mozi]. Yindu Xuekan 殷都学刊 4:102-105.

LI, Ji

1977 Anyang. Seattle: University of Washington Press.

Li MiN 李旻

2017 Chongfan Xiaxu: Shehui Jiyi Yu Jingdian De Fasheng 重返夏墟: 社会记忆与经典的 发生 [Coming back to Xiaxu: Social memory and the emergence of classical tradition]. Kaogu Xuebao 考古学报 3:287-316. 
Liv, LI

1996 Settlement patterns, chiefdom variability, and the development of early states in North China. Journal of Anthropological Archaeology 15(3):237-288.

2000 Ancestor worship: An archaeological investigation of ritual activities in Neolithic North China. Journal of East Asian Archaeology 2(1-2):129-164.

2003 "The production of minds as well as of hands": Production of prestige goods in the Neolithic and Early State periods of China. Asian Perspectives 42(1):1-40.

Liu, Li, AND Chen XingCan

2005 The Chinese Neolothic: Trajectories to Early States. Cambridge: Cambridge University Press.

2012 The Archaeology of China: From the Late Paleolithic to the Early Bronze Age. Cambridge: Cambridge University Press.

LuO Kun 罗琨

2010 Shangdai Zhanzheng Yu Junzhi 商代战争与军制 [Shang Dyansty Wars and Military System]. Beijing: China Social Sciences Press.

Ma XIAOLIN

2005 Emergent Social Complexity in the Yangshao Culture: Analyses of Settlement Patterns and Faunal Remains from Lingbao, Western Henan, China (c. 4900-3000 B.C.). Bar International Series 1453. Oxford: British Archaeological Reports.

Mozi 墨子

1993 Mozi Jiaozhu 墨子校注 [Annotations on the Mozi] by Wu Yujiang 吴毓江, annotated by Sun Qizhi 孙启治. Beijing: Zhonghua Press Company.

QU WANLI 屈万里

1984 Yinxu Wenzi Jiabian Kaoshi 殷墟文字甲编考释 [Notes to the Yinxu Inscriptions: Part One]. Taipei: Lianjing Press Company.

RoBb, JoHn E.

1998 The archaeology of symbols. Annual Review of Anthropology 27:329-346.

SHANDONG SHeng Wenwu KaOgu YanjIUSUO 山东省文物考古研究所

2015 Shouguang Bianxianwang Longshan Wenhua Chengzhi De Kaogu Fajue 寿光边线王龙山文化城 址的考古发掘 [The Excavation on the City Site of Longshan Culture at Bianxianwang, Shouguang]. Haidai Kaogu (Di Ba Ji) 海岱考古 (第八辑) [Haidai Archaeology 8]. Beijing: Science China Press.

SHANDONG SHeng Wenwu KaOgu YanjIUSUO 山东省文物考古研究所 AND Liaocheng DiQU WENHUAJU WENWU YANJIUSHI 聊城地区文化局文物研究室

1997 Shandong Yanggu Jingyanggang Longshan Wenhua Chengzhi Diaocha Yu Shijue 山东阳谷 景阳岗龙山文化城址调查与试掘 [Survey and excavation at the city site of Longshan Culture in Jingyanggang Village, Yanggu County, Shandong]. Kaogu 考古 5:11-24.

SHANGSHU 尚书

2014 Shangsh $u$ [The She King], trans. James Legge. Shanghai: Joint Publishing Press.

SHANNXI SHENG KaOgU YanjiUyuan 陕西省考古研究院, Yulin Shi Wenwu KaOgu Kantan GONGZUODUI 榆林市文物考古勘探工作队, AND SHENMU XIAN WENTIJU 神木县文体局

2013 Shannxi Shenmu Xian Shimao Yizhi 陕西神木县石峁遗址 [The Shimao site in Shenmu County, Shanxi Province]. Kaogu 考古 7:15-24.

Shelach, Gideon, and Yitzhak Jaffe

2014 The earliest states in China: A long-term trajectory approach. Journal of Archaeological Research 22(4):327-364.

SHI Yafeng 施雅风, Kong ZhaOchen 孔昭宸, AND Wang Sumin 王苏民

1992 Zhongguo Quanxinshi Danuanqi Qihou Yu Huanjing De Jiben Tezheng 中国全新世大暖期 气候马环境的基本特征 [The charateristics of the climates and environments of Holocene Megathermal in China], in Zhongguo Quanxinshi Danuanqi Qihou Yu Huanjing 中国全新世大 暖期气候与环境 [The climates and environments of Holocene Megathermal in China]: 1-18, ed. Shi Yafeng and Kong Zhaochen. Beijing: Science Press.

SHI YAFEng 施雅风, Kong ZhaOchen 孔昭宸, WANg SUMin 王苏民, TANG LingYu 唐领余, Wang FUBAO 王富葆, YAO TANDONG 姚檀栋, ZHAO XITAO 赵希涛, ZHANG PIYUAN 张丕远, AND SHI SHAOHUA 施少华

1993 Mid-Holocene climates and environments in China. Global and Planetary Change 7:219-233. 
SHIJI 史记

1959 Shiji 史记 [Records of the Grand Historian], by Shimaqian 司马迁. Beijing: Zhonghua Press.

SHOUCHENGLU 守城录

1990 Shouchenglu Zhushi 守城录注释 [Annotations on Shouchenglu], annotated by Lin Zhengcai 林正才. Beijing: People's Liberation Army Press.

SirÉn, OSVALD

1924 The Walls and Gates of Peking. London: John Lane.

Smith, Michael E.

2002 Domestic ritual at Aztec provincial sites in Morelos, in Domestic Ritual in Ancient Mesoamerica: 93-114, ed. Patricia Plunkett. Los Angeles: UCLA Cotsen Institute of Archaeology.

SONG ZHENHAO 宋镇豪

2010 Shangdai Shehui Shenghuo Yu Lisu 商代社会生活与礼俗 [Social Lives and Rituals in the Shang Dynasty]. Beijing: China Social Sciences Press.

SugIYAma, NAwA

2014 Animals and Sacred Mountains: How Ritualized Performances Materialized State-ideologies at Teotihuacan, Mexico. Ph.D. diss. Harvard University.

Tang Jigen, Jing Zhichun, and George Rapp

2000 The largest walled Shang city located in Anyang, China. Antiquity 74:479-480.

Trigger, Bruce G.

1990 Monumental architecture: A thermodynamic explanation of symbolic behaviour. World Archaeology 22(2):319-332.

UNDERHILL, ANNE

1989 Warfare during the Chinese Neolithic period: A review of the evidence, in Cultures in Conflict: Current Archaeological Perspectives: 229-237, ed. Diana Claire Tkaczuk and Vivian Brianc. Alberta: Archaeological Association of the University of Calgary.

2002 Craft Production and Social Change in Northern China. New York: Kluwer Academic.

VON FALKenhausen, LothaR

2008 Stages in the development of "cities" in Ancient China, in The Ancient City: New Perspectives on Urbanism in the Old and New World: 209-228, ed. Joyce Marcus and Jeremy A. Sabloff. Sante Fe, NM: School for Advanced Research Press.

WANG JIANHUA 王建华

2011 Huanghe Zhongxiayou Diqu Shiqian Renkou Yanjiu 黄河中下游地区史前人口研究 [Research on Prehistoric Demographics in the Middle and Lower Yellow River Region]. Beijing: China Science Press.

WANG YUXIN 王宇信 AND YANG SHENGNAN 杨升南

1999 Jiaguxue Yibai Nian 甲骨学一百年 [A Century of Study of Oracle Bone and Shell Inscriptions]. Beijing: Social Science Press.

WANG ZIJIN 王子今

1995 Qindegong Zhegou Yi Simen Zongjiao Wenhua Yiyi Shishuo 秦德公“磔狗邑四门”宗教文 化意义试说 [The Duke of Qin De's “Killing Dogs At Four Gates” and its cultural meaning]. Zhongguo Wenhua 中国文化 12:133-139.

WeIss, HaRvey

2000 Beyond the Yonger Dryas: Collapse as adaptation to abrupt climate change in Ancient West Asia and the Eastern Mediterranean, in Environmental Disaster and the Archaeology of Human Response: 75-98, ed. Garth Bawden and Richard M. Reycraft. Albuquerque, NM: Maxwell Museum of Anthropology.

WEN SHAOFENG 温少峰 AND YUAN TINGDONG 袁庭栋

1983 Yinxu Buci Yanjiu: Kexue Jishupian 殷墟卜辞研究: 科学技术篇 [Research on Oracle Bones: Chapter on Science and Technology]. Chengdu: Sichuan Provincial Social Science Press.

XIE SU 谢肃

2015 Shang Wenhua Yu Chengqiang Youguan De Jisi Yicun Qianxi 商文化与城墙有关的祭祀遗 存浅析 [Sacrifical offering remains related to city walls in Shang Culture]. Kaogu Yu Wenwu 考古与文物 3:41-43. 
Xu LONGGUO 徐龙国

2015 Zhongguo Gudai Ducheng Mendao Yanjiu 中国古代都城门道研究 [Research on the gateways of the ancient capital city gates of China]. Kaogu Xuebao 考古学报 4:425-449.

Xu SHUNZHAN 许顺湛

2002 Shanxi Yangshao Wenhua Juluoqun De Qishi 陕西仰韶文化聚落群的启示. [Inspiration for the Yangshao Cultural Settlement Pattern in Shaanxi]. Zhongyuan Wenwu 中原文物 4:7-13.

YANG BAOCHENG 杨宝成

2002 Yinxu Wenhua Yanjiu 殷墟文化研究 [Yinxu Culture Research]. Wuhan: Wuhan University Press.

YANG GUOQING 杨国庆

2002 Ming Nanjing Chengqiang Zhucheng Renyuan Goucheng Ji Yonggongliang Chutan 明南京 城墙筑城人员构成及用工量初探 [Study on the demographics of the laborers who built the city wall of Nanjing]. Dongnan Wenhua 东南文化 1:37-44.

YANG SHENGNAN 杨升南 AND MA JIFAN 马季凡

2010 Shangdai Jingji Yu Keji 商代经济与科技 [Shang Dynasty Economy and Technology]. Beijing: China Social Sciences Press.

Yuan, Jing, AND Rowan K. Flad

2005 New zooarchaeological evidence for changes in Shang Dynasty animal sacrifice. Journal of Anthropological Archaeology 24:252-270.

ZHANG GuOSHUO 张国硕 AND YIN ChUnZHI 阴春枝

1997 Woguo Xinshiqi Shidai Chengzhi Zonghe Yanjiu 我国新石器时代城址综合研究 [Comprehensive research on Chinese Neolithic walled-town sites]. Zhengzhou Daxue Xuebao (Zhexue Shehui Kexueban) 郑州大学学报 (哲学社会科学版) 2:58-62.

ZHANG XUEHAI 张雪海

1996 Shilun Shandong Diqu De Longshan Wenhuacheng 试论山东地区的龙山文化城 [Studies on Longshan cities in Shandong]. Wenwu 文物 12:40-52.

ZHAO HUI 赵辉 AND WEI JUN 魏峻

2002 Zhongguo Xinshiqi Shidai Chengzhi De Faxian Yu Yanjiu 中国新石器时代城址的发现与 研究 [Findings and research on Chinese Neolithic walled-town sites], in Gudai Wenming 古代 文明 [Ancient Civilization], vol. 1: 1-34, ed. The Chinese Archaeological Research Centre, Peking University. Beijing: Relics Press.

ZHENGZHOU SHI WENWU KAOGU YANJIUYUAN 郑州市文物考古研究院

2016 Xinzheng Wangjinglou: 2010-2012 Nian Tianye Kaogu Fajue Baogao 新郑望京楼: 2010-2012 年田野考古发掘报告 [Wangjinglou Site in Xinzheng: Excavation Report of 2010-2012]. Beijing: Science China Press.

Zhongguo Lishi Bowuguan Kaogubu 中国历史博物馆考古部, Shanxi Sheng Kaogu Yanjiusuo 山西省考古研究所, AND YUANQU XIAN BOWUGUAN 垣曲县博物馆

1996 Yuanqu Shangcheng 垣曲商城 (1985-1986 年度勘察报告) [The Shang Period Walled Site at Yuanqu: Report of Surveys 1985-1986]. Beijing: Science China Press.

ZhongGuo SheHui KeXueyuan KaOgu YanjIUsuo 中国社会科学院考古研究所

2002 Henan Yanshi Shangcheng Zaoqi Wangshi Jisi Yizhi 河南偃师商城商代早期王室祭祀遗址 [Early Shang sacrifical site in the Shang walled site at Yanshi, Henan]. Kaogu 考古 7:6-8.

Zhongguo Shehui Kexueyuan KaOgu Yanjiusuo 中国社会科学院考古研究所 AND Henan Sheng WENWU KAOGU YANJIUSUO 河南省文物考古研究所.

2010 Lingbao Xipo Mudi 灵宝西坡墓地 [The Cemetery of Xipo at Lingbao]. Beijing: Relics Press.

Zhongguo Shehui KeXueyuan KaOgu Yanjiusuo ANyAng GONGZUOdui 中国社会科学院考古研究所 安阳工作队

2003 Henan Anyang Shi Huanbei Shangcheng De Kancha Yu Shijue 河南安阳市洹北商城的勘 察与试掘 [Survey and trial excavation of the Shang period Huanbei city site in Anyang City, Henan]. Kaogu 考古 (5):3-16.

Zhongguo Shehui Kexueyuan Kaogu Yanjiusuo ShanXidui 中国社会科学院考古研究所山西队, ShanXi SHENG Kaogu Yanjiusuo 山西省考古研究所, AND Linfen Shi Wenwuju 临汾市文物局

2005 Shanxi Xiangfen Taosi Chengzhi 2002 Nian Fajue Baogao 山西襄汾陶寺城址 2002 年发掘 报告 [Excavation on the city site at Taosi, Xiangfen, Shanxi in 2002]. Kaogu Xuebao 考古学报 (3):307-345. 
Zhongguo Shehui Kexueyuan Kaogu Yanjiusuo Luoyang Hanwei Gucheng Gongzuodui 中国社会 科学院考古研究所洛阳汉魏故城工作队

1984 Yanshi Shangcheng De Chubu Kantan He Fajue 偃师商城的初步勘探和发掘 [Reconnaissance and excavation of the Yanshi Shang site, Henan]. Kaogu 考古 6:488-504.

Zhongguo SheHui KeXueyuan KaOgu Yanjiusuo Shandongdui 中国社会科学院考古研究所山东队, Shandong Sheng Wenwu KaOgu Yanjiusuo 山东省文物考古研究所, AND Liaocheng Shi Wenwuju 聊城市文物局

2005 Shandong Chiping Jiaochangpu Yizhi Longshan Wenhua Chengqiang De Faxian Yu Fajue 山 东茌平教场铺遗扯龙山文化城墙的发现与发掘 [The finding and excavation of a Longshan Culture city wall at Jiaochangpu site, Chiping, Shandong]. Kaogu 考古 1:3-6.

ZOU HENG

1999 The Yanshi Shang city: A secondary capital of the Early Shang, Festschrift in Honor of Professor Kwang-Chih Chang (special issue). Journal of East Asian Archaeology 1(1-4):195-205. Cambridge: Peabody Museum Press.

ZUOZHUAN 左传

1996 Zuozhuan 左传 [Zuo's Commentary], trans. Huzhihui 胡志挥. Changsha: Hunan Publishing House. 